\title{
ACTIVATION OF ENDOGENOUS INTOXICATION UNDER THE INFLUENCE OF ANESTHETICS IN EXPERIMENTAL HYPERTHYROIDISM
}

\author{
Olexander M. Yakymchuk, Ivan M. Klishch, Alla V. Boychuk, Yuliia B. Yakymchuk \\ I. HORBACHEVSKY TERNOPIL NATIONAL MEDICAL UNIVERSITY, TERNOPIL, UKRAINE
}

\begin{abstract}
The aim: To determine the features of endogenous intoxication in the blood of experimental animals in the setting of simulated hyperthyroidism under the influence of various anesthetics.

Materials and methods: Rats were injected L-thyroxine to simulate hyperthyroidism, and sodium thiopental and dexmedetomidine in the setting of euthyroidism and hyperthyroidism.

Results: An increase in the activity of endogenous intoxication, the content of medium-molecular peptides (MMW1, MMW2) and their coefficient (K= MSM2 / MSM1) were observed in the erythrocytes of experimental animals with hyperthyroidism. A significant difference in the rates of endogenous intoxication with the use of sodium thiopental and dexmedetomidine hydrochloride in the setting of euthyroidism and hyperthyroidism has been determined.

Conclusions: In experimental hyperthyroidism in rats, an increase in the level of endogenous intoxication has been determined, which is indicated by an increase in the permeability of erythrocyte membranes and an increase in the level of macromolecular fractions of medium-weight molecules in the blood.The use of sodium thiopental and dexmedetomidine in the setting of euthyroidism and hyperthyroidism is accompanied by pronounced changes in the body of experimental animals, namely: increased endogenous intoxication, which deepens the destructive changes in the organs and systems of experimental animals.
\end{abstract}

KEY WORDS: endogenous intoxication, hyperthyroidism, sodium thiopental, dexmedetomidine

Wiad Lek. 2020;73(10):2224-2226

\section{INTRODUCTION}

In terms of the total frequency of endocrine pathology among the population diseases of the thyroid gland are in the first place. This pathology causes clinical manifestations of many syndromes and severe disorders, including cardiovascular disorders and related diseases, at least 200 million people are affected, which causes a lot of medical and social problems $[1,2]$.

High risks of intra- and postoperative complications are associated with the direct toxic effects of thyroid hormones excess on the cardiovascular, nervous and other body systems. The high degree of variability of these effects on the body justifies the topicality of the problem of anesthetic care optimization during urgent operations for various nosologies secondary to thyroid pathology, which is exacerbated by preoperative stress. Many years of use of various methods of general anesthesia have shown that they can not prevent intraoperative damaging stress stimulation and homeostasis disorders [3].

Sodium thiopental has side effects in therapeutic doses: irritating local action, especially when injected into the peritoneum, suppressing effect on the respiratory, vascular centers and the heart. In addition, it should be administered slowly, as rapid administration causes respiratory arrest and collapse $[4,5]$.
Qualitatively performed randomized clinical trials have shown that dexmedetomidine has pronounced analgesic, sedative, hypnotic and sympatholytic properties. In fact, it has been confirmed that this class of medicines effectively reduces intraand postoperative stress response. When using low doses, the dominant action of $a 2$-agonists is sympatholytic, i.e. the ability to block the sympathetic parts of the autonomic nervous system, mediated by a2-adrenergic receptors of the $2 \mathrm{~A}$ subtype [6].

Endogenous intoxication is a universal nonspecific syndrome, which is characteristic of various systemic processes with the formation of toxic products. Toxins have the ability to cause the destruction of plasma membranes, which in turn leads to the activation of apoptosis, release of toxins into the blood, development of toxemia, and causes generalized toxic reaction. Therefore, it was interesting to compare the effect of those anesthetics on the endogenous intoxication of rats using the model of experimental hyperthyroidism $[5,10]$.

This model is well studied, and it shows that hyperthyroidism, which is simulated in experimental animals, in its effect on homeostasis is similar to equivalent changes in human homeostasis.

\section{THE AIM}

The aim of the study was to determine the features of the course of endogenous intoxication in the blood of experi- 
mental animals under the influence of various anesthetics in simulated hyperthyroidism.

\section{MATERIALS AND METHODS}

The study was performed on 60 adult white outbred male rats weighing $(160 \pm 5) \mathrm{g}$, which were managed in standard vivarium conditions. All manipulations with the experimental animals were carried out in compliance with the rules of the «European Convention for the Protection of Vertebrate Animals used for Experimental and other Scientific Purposes», as well as according to "Guidelines on the Care of Laboratory Animals and Their Use for Scientific Purposes» $[8,9,10]$.

Experimental animals were divided into the following groups: group I - intact animals (10 rats); group II - animals with simulated experimental hyperthyroidism (10 rats); group III - animals which were administered sodium thiopental in the setting of euthyrosis (10 rats); group IV - animals which received sodium thiopental in the setting of experimental hyperthyroidism (10 rats); group $\mathrm{V}$ - animals which were administered dexmeditimedin in the setting of euthyroidism (10 rats), group VI - animals which were administered dexmedetomidine in the setting of experimental hyperthyroidism (10 rats) (Table 1 ).

Hyperthyroidism was simulated by intragastric administration of L-thyroxine in $1 \%$ starch solution at a daily dose of $200 \mu \mathrm{g}$ per $1 \mathrm{~kg}$ of body weight for 21 days [7]. Sodium thiopental was administered intraperitoneally at a rate of $20 \mathrm{mg} / \mathrm{kg}$ of body weight of rats $[4,8]$. Dexmedetomidine hydrochloride was administered intraperitoneally at a rate of $1 \mathrm{mg} / \mathrm{kg}$ of body weight of experimental animals [6].

Table 1. Division of animals into groups

\begin{tabular}{ccc}
$\begin{array}{c}\text { Group } \\
\text { of animals }\end{array}$ & $\begin{array}{c}\text { Number } \\
\text { of animals }\end{array}$ & $\begin{array}{c}\text { Type } \\
\text { of anesthesia }\end{array}$ \\
\hline group I & 10 & euthyrosis \\
\hline group II & 10 & hyperthyroidism \\
\hline group III & 10 & sodium thiopental + euthyrosis \\
\hline group IV & 10 & $\begin{array}{c}\text { sodium thiopental + } \\
\text { hyperthyroidism }\end{array}$ \\
\hline group V & 10 & dexmedetomidine + euthyrosis \\
\hline group VI & 10 & $\begin{array}{r}\text { dexmedetomidine + } \\
\text { hyperthyroidism }\end{array}$ \\
\hline
\end{tabular}

Plasma toxicity was assessed by erythrocyte intoxication index (EII) [11] and by the content of medium-molecular peptides, as well as their low- and high-molecular fractions. The content of molecules with medium molecular weight (MMW) was calculated by determining their coefficient (C= MMW2/MMW1, where MMW2- MMW, determined at $\mathrm{l}=280 \mathrm{~nm}$; MMW1- MMW, determined at $\mathrm{l}=254 \mathrm{~nm}$ ) according to Oskin and Chekalin method (1987) [11]. The digital material obtained as a result of the experiment was systematized and processed using the methods of variation statistics with the program «Microsoft Exel 10.0». Statistical processing of the results was performed using Student t-test. Data are presented as arithmetic mean and mean absolute error $(\mathrm{M} \pm \mathrm{m})$. The difference between the studied indicators was considered as statistically significant at a value of $\mathrm{P} \leq 0.05$.

\section{RESULTS AND DISCUSSION}

Pathological activation of endogenous intoxication of the body is considered as one of the most important criteria that determines the severity of patient's condition and necessitates the appointment of various types of detoxification therapy. One of the ways to diagnose endogenous intoxication is to study the permeability of erythrocyte membranes [12].

Important markers of endogenous toxic syndrome are the determination of medium molecular weight peptides (MMW2 and MMW1). In experimental hyperthyroidism there is an increase in the fraction of MMW with a higher molecular weight, which are the products of degradation of enzymes, nucleotides and structural proteins. In group II, the level of MMW1 increased by 28\%, and MMW2 by $38 \%$, CMMW - by $4 \%$. ( $<<0.05)$ compared with the control group of animals. The increase in CMMW in the group of animals with hyperthyroidism compared with healthy ones, indicates an increase in aromatic amino acids in the peptide components of medium molecular weight peptides (Table 2).

With the use of sodium thiopental in the setting of euthyroidism (group III), the content of MMW1 increased by $23 \%$, MMW 2 - by $28 \%$ and CMMW - by $2 \%$ against a significant increase of MMW 1 by $103 \%$, MMW 2 - by $89 \%$ and CMMW - by $13 \%(\mathrm{p}<0.05)$ with the administration of sodium thiopental in the setting of hyperthyroidism (group IV). With the use of dexmedetomidine in the set-

Table 2. The level of endogenous intoxication in white rats under the influence of various anesthetics in simulated hyperthyroidism ( $M \pm m), n=10$

\begin{tabular}{|c|c|c|c|c|c|c|}
\hline Indices & I group & II group & III group & IV group & V group & VI group \\
\hline $\mathrm{El}, \%$ & $\begin{array}{c}48,39 \pm \\
1,6\end{array}$ & $\begin{array}{c}72,19 \pm \\
0,61\end{array}$ & $\begin{array}{c}57,45 \pm \\
1.31^{*}\end{array}$ & $\begin{array}{c}91,15 \pm \\
0,83^{*}\end{array}$ & $\begin{array}{c}49,59 \pm \\
1,04^{*}\end{array}$ & $\begin{array}{c}75,18 \pm \\
1,44\end{array}$ \\
\hline MMW 1 & $\begin{array}{c}0,40 \pm \\
0,01 \\
\end{array}$ & $\begin{array}{c}0,52 \pm \\
0,01 \\
\end{array}$ & $\begin{array}{l}0,49 \pm \\
0,01^{*}\end{array}$ & $\begin{array}{l}0,81 \pm \\
0,01^{*}\end{array}$ & $\begin{array}{l}0,45 \pm \\
0,01^{*}\end{array}$ & $\begin{array}{c}0,53 \pm \\
0,01\end{array}$ \\
\hline MMW 2 & $\begin{array}{c}0,42 \pm \\
0,01\end{array}$ & $\begin{array}{c}0,57 \pm \\
0,01\end{array}$ & $\begin{array}{l}0,53 \pm \\
0,01^{*}\end{array}$ & $\begin{array}{l}0,78 \pm \\
0,01^{*}\end{array}$ & $\begin{array}{l}0,48 \pm \\
0,01^{*}\end{array}$ & $\begin{array}{c}0,57 \pm \\
0,01\end{array}$ \\
\hline CMMW & $\begin{array}{c}0,969 \pm \\
0,002\end{array}$ & $\begin{array}{c}1,012 \pm \\
0,002\end{array}$ & $\begin{array}{l}0,987 \pm \\
0,009^{*}\end{array}$ & $\begin{array}{c}1,093 \pm \\
0,029\end{array}$ & $\begin{array}{c}0,978 \pm \\
0,014\end{array}$ & $\begin{array}{c}1,041 \pm \\
0,019\end{array}$ \\
\hline
\end{tabular}


ting of euthyroidism (group V) MMW1 increased by $12 \%$, MMW 2 - by $14 \%$ and CMMW - by $1 \%$ against an increase of MMW 1 by $33 \%$, MMW 2 - by $41 \%$ and CMMW - by $7 \%$ in the group of animals with dexmedetomidine secondary to hyperthyroidism (group VI), which brought those indicators closer to the II group of animals ( $p>0,05)$ (Table 2). It can be noted that when using dexmedetomidine in the $\mathrm{V}$ and VI groups, indices of endogenous intoxication increased to a lesser extent than when using sodium thiopental in the III and IVgroups respectively.

In cases of thyrotoxicosis toxemia (group II) there was a significant increase in the index of endogenous intoxication of EI to $(72.19 \pm 0.6) \%$, while in groups III and IV those indicators increased to $(57.45 \pm 1.31) \%$ and $91.15 \pm 1.04) \%$, respectively, which significantly $(\mathrm{p}<0.05)$ exceeded the indicators of group I $(48.39 \pm 1.6) \%$.

Thus, a long-term increase in the rate of endogenous intoxication, apparently, leads to intensification of damage to the cell membranes in animals, triggering of increased apoptosis, accumulation of toxic products in the blood, toxemia, which is a consequence of their direct action on the membrane wall of not only erythrocytes but also other cells of target organs. The toxic effect of analgesics deepens these pathological processes and requires the search for medicines with a protective effect.

\section{CONCLUSIONS}

In experimental hyperthyroidism, an increase in the level of endogenous intoxication was found in the body of rats, which is indicated by an increase in the permeability of erythrocyte membranes and in the level of high molecular weight fractions of medium-weight molecules.

The use of sodium thiopental and dexmedetomidine in the setting of euthyroidism and hyperthyroidism is accompanied by pronounced changes in the body of experimental animals, namely: increased endogenous intoxication, which deepens the destructive changes in the organs and systems of experimental animals.

In our further research we plan to study the activity of apoptosis and necrosis, the state of the redox system, enzymatic and non-enzymatic parts of the antioxidant system using various analgesics in the setting of hyperthyroid intoxication, as well as to develop methods of pathogenetically proved correction of detected changes.

\section{REFERENCES}

1. Haugen B.R., Alexander E.K., Bible K.C. et al. American Thyroid Association Management Guidelines for Adult Patients with Thyroid Nodules and Differentiated Thyroid Cancer: The American Thyroid Association Guidelines Task Force on Thyroid Nodules and Differentiated Thyroid Cancer. Thyroid. 2016;2691):1-133.

2. Orzechowska-Pawilojc A., Siekierska-Hellmann M., Syrenicz A. et al. Homocysteine, folate, and cobalamin levels in hyperthyroid women before and after treatment. Endokrynol. Pol. 2009;60(6):443-448.

3. Oleinyk V.A., Markov V.V., Gulevatyi S.V. i dr. Klinicheskii protokol posleopieracyonnogo vedeniia bolnykh diferencyrovannym rakom shchitovidnoi zhelezy. Liky Ukrainy. 2010;146(10):73-75.
4. Pat. Ukrainy na korysnu model № (19)UA (11)3386 (13)U 7 A61B17/00,A61K31/00 (54) Sposib zneboliuvannia u shchuriv pry operatyvnykh vtruchanniakh na shlunku. Stepaniuk G. I., Shevchyk 0.K. Biul. № 11, 2004r15.11.2004

5. Olenovych O.A., Perepeliuk M.D. Stan pro- ta antyoksydantnoi systemy krovi i shchytopodibnoi zalozy pry eksperymentalnomu hipoteryozi. Medychna himiia. 2007;9(7):97-102.

6. Pavlov 0.0., Podrez E.V. Misce a2-aganistiv u kompleksi skhemy zneboliuvannia. Medycyna neotlozhnykh sostoianii. 2014;8:9-12.

7. NechyporukV.M.,Zaichenko N.V., Korda M.M. Vplyv tyreoidnykh hormoniv na procesy remytyluvannia ta transsulfyvannia sirkovmisnykh aminokyslot v organakh shchuriv. Medychna ta klinichna himiia. 2017;19(1):12-16.

8. Vasiutyna M.L., Smyrnova S.V. Sravnitelnyi analiz preparatov ispolzuiemykh dlia obshchei anestezii u krys. Vesnik Novgorodskogo gosudarstwiennogo universiteta. 2015;86(1):41-43.

9. Kozhemiakin Yu.M., Khromov 0.S., Filonenko M.A. i dr. Naukovopraktychni rekomendacii z utrymannia laboratornykh tvaryn ta roboty z nymy. Kyiv: Avicena, 2002 p. 156.

10. Seredynska N.M., Mokhort M.A., Kyrychok L.M. Bolova chutlyvist ta adekvatnist ii ocinky za testom «tail-flick» u bilikh shchuriv. Farmakologiia ta likarska toksykologiia. 2014;3(39):45-51.

11. Gabrielian N.I., Lipatova V.I. Opredelenie soderzhaniia sredniemoliekuliarnykh peptidov v krovi. Lab. Delo. 1984; 3:138-140.

12. Nikolaichyk V.V., Moin V.M., Kirkovskii V.V. i dr. Sposob opredeleniia „srednikh molekul”. Lab. Delo. 1991;10:13- 18.

The work is carried out within the framework of the research work "Optimization of diagnosis and prevention of diseases of the reproductive system and development of pathogenically grounded methods for their correction" (state registration number 011U001801).

\section{ORCID and contributionship:}

Olexander M. Yakymchuk: 0000-0002-6369-042X ${ }^{A, B, C, D, E}$

Ivan M. Klishch: 0000-0001-6226-4296 ${ }^{A, B, C, F}$

Alla V. Boychuk: 0000-0002-2191-0383 D,F

Yuliia B. Yakymchuk: 0000-0002-3905-1310 B,F

\section{Conflict of interest:}

The Authors declare no conflict of interest

\section{CORRESPONDING AUTHOR \\ Alla V. Boychuk}

Department of Obstetrics and Gynecology

Faculty of Postgraduate Education of Educational and Scientific Institute I. Horbachevsky Ternopil National Medical University,

str. Maidan Voli, 1, 46001, Ternopil, Ukraine

tel: +380673025808

e-mail: appag@ukr.net

Received: 07.06 .2020

Accepted: 28.08 .2020

A - Work concept and design, B - Data collection and analysis, C - Responsibility for statistical analysis,

D-Writing the article, $\mathbf{E}-$ Critical review, $\mathbf{F}-$ Final approval of the article 